\title{
Assessment of antiproliferative and antiplasmodial activities of five selected Apocynaceae species
}

\author{
Siu Kuin Wong ${ }^{1}$, Yau Yan Lim", Noor Rain Abdullah², Fariza Juliana Nordin²
}

\begin{abstract}
Background: Studies have shown that the barks and roots of some Apocynaceae species have anticancer and antimalarial properties. In this study, leaf extracts of five selected species of Apocynaceae used in traditional medicine (Alstonia angustiloba, Calotropis gigantea, Dyera costulata, Kopsia fruticosa and Vallaris glabra) were assessed for antiproliferative (APF) and antiplasmodial (APM) activities, and analysed for total alkaloid content (TAC), total phenolic content (TPC) and radical-scavenging activity (RSA). As V. glabra leaf extracts showed wide spectrum APF and APM activities, they were further screened for saponins, tannins, cardenolides and terpenoids.

Methods: APF and APM activities were assessed using the sulphorhodamine B and lactate dehydrogenase assays, respectively. TAC, TPC and RSA were analysed using Dragendorff precipitation, Folin-Ciocalteu and DPPH assays, respectively. Screening for saponins, tannins, cardenolides and terpenoids were conducted using the frothing, ferric chloride, Kedde and vanillin- $\mathrm{H}_{2} \mathrm{SO}_{4}$ tests, respectively.

Results: Leaf extracts of A. angustiloba, C. gigantea and V. glabra displayed positive APF activity. Dichloromethane (DCM) extract of C. gigantea, and DCM and DCM:MeOH extracts of $V$. glabra showed strong APF activity against all six human cancer cell lines tested. DCM extract of $A$. angustiloba was effective against three cancer cell lines. Against MCF-7 and MDA-MB-231 cell lines, DCM extract of C. gigantea was stronger than standard drugs of xanthorrhizol, curcumin and tamoxifen. All five species were effective against K1 strain of Plasmodium falciparum and three species (C. gigantea, D. costulata and K. fruticosa) were effective against 3D7 strain. Against K1 strain, all four extracts of $V$. glabra displayed effective APM activity. Extracts of $D$. costulata were effective against 3D7 strain. Selectivity index values of extracts of A. angustiloba, C. gigantea and V. glabra suggested that they are potentially safe for use to treat malaria. Extracts of $K$. fruticosa had the highest TAC while D. costulata had the highest TPC and RSA. Phytochemical screening of extracts of $V$. glabra also showed the presence of terpenoids, tannins and saponins.

Conclusions: Leaf extracts of $C$. gigantea and $V$. glabra showed great promise as potential candidates for anticancer drugs as they inhibited the growth of all six cancer cell lines. Against K1 strain of P. falciparum, all four extracts of $V$. glabra displayed effective APM activity. The wide spectrum APF and APM activities of $V$. glabra are reported for the first time and this warrants further investigation into its bioactive compounds.
\end{abstract}

\section{Background}

The family Apocynaceae consists of about 250 genera and 2000 species of tropical trees, shrubs and vines [1,2]. A characteristic feature of the family is that almost all species produce milky sap. Leaves are simple, opposite and whorled. Flowers are large and colourful.

\footnotetext{
* Correspondence: lim.yau.yan@sci.monash.edu.my

'School of Science, Monash University Sunway Campus, Bandar Sunway, 46150 Petaling Jaya, Selangor, Malaysia

Full list of author information is available at the end of the article
}

In traditional medicine, Apocynaceae species are used to treat gastrointestinal ailments, fever, malaria, pain and diabetes [2]. Of the five species studied, roots and leaves of Calotropis gigantea (L.) Aiton are used to treat skin and liver diseases, leprosy, dysentery, worms, ulcers, tumours and earaches [3]. Its latex has been reported to have wound healing properties [4]. Kopsia fruticosa (Ker.) A. DC. is used to treat sore and syphilis, and has cholinergic effects [5]. Leaves and barks of Dyera costulata Hook have been used for treating fever, inflammation and pain [6]. Stems, leaves and latex of Alstonia 
angustiloba Miq. have been used for gynaecological problems and skin sores in Indonesia [7]. Leaves are externally applied to treat headache in Malaysia [8]. Vallaris glabra Kuntze is well known in Thailand because the scent of its flowers is similar to that of pandan leaves and aromatic rice [9]. Its use in traditional medicine has not been reported, and its bioactivity and phytochemistry have yet to be studied. Species of Apocynaceae have also been reported to possess anticancer properties $[2,10]$. Species having cytotoxic activity include those of Allamanda [11], Alstonia [12,13], Cerbera [14,15], Nerium [16,17], Plumeria [18] and Tabernaemontana [19]. Species of Apocynaceae, notably those of Alstonia, are also known to have antimalarial properties [20-22].

Prompted by the anticancer and antimalarial properties of Apocynaceae, leaf extracts of five selected species used in traditional medicine were assessed for antiproliferative (APF) activity against six human cancer cell lines and for antiplasmodial (APM) activity against two strains of Plasmodium falciparum. Their extracts were also analysed for total alkaloid content, total phenolic content and radical-scavenging activity. Having wide spectrum APF and APM activities, leaf extracts of $V$. glabra were further screened for saponins, tannins, cardenolides and terpenoids. Information from the screening will serve as a useful guide to further work on isolating compounds with APF and APM activities.

\section{Methods}

Plant materials

Species studied were A. angustiloba, C. gigantea, D. costulata, K. fruticosa and $V$. glabra. Leaf samples of $A$. angustiloba, $C$. gigantea and $V$. glabra were collected from Puchong ( ${ }^{\circ} 2^{\prime} 42^{\prime \prime N}$; 101 $\left.37^{\circ} 12^{\prime \prime E}\right)$, Sunway $\left(3^{\circ} 4^{\prime} 30^{\prime \prime} \mathrm{N} ; 101^{\circ} 36^{\prime} 8^{\prime \prime} \mathrm{E}\right)$ and Kepong $\left(3^{\circ} 12^{\prime} 14^{\prime \prime} \mathrm{N}\right.$; $101^{\circ} 37^{\prime} 50^{\prime E}$ ) in Selangor, Malaysia, respectively. Those of $D$. costulata and $K$. fruticosa were collected from the Forest Research Institute Malaysia $\left(3^{\circ} 14^{\prime} 6^{\prime \prime} \mathrm{N}\right.$; $\left.101^{\circ} 37^{\prime} 58^{\prime \prime} \mathrm{E}\right)$. Identification of species was based on documented descriptions and illustrations [1,2]. With brief descriptions of their morphology and location of collection, the voucher specimens of these species (WSK01, WSK02, WSK03, WSK04 and WSK05, respectively) were deposited in the herbarium of Monash University Sunway Campus in Malaysia.

\section{Extraction of leaves}

For crude extraction, fresh leaves of each species (40 g) were cut into small pieces and freeze-dried overnight. Dried samples were blended and extracted with $250 \mathrm{ml}$ of methanol $(\mathrm{MeOH})$ three times for $1 \mathrm{~h}$ each time. Samples were filtered and the solvent was removed using a rotary evaporator (Eyela). The dried crude extracts were stored at $-20^{\circ} \mathrm{C}$ for further analysis. For sequential extraction, fresh leaves of each species (40 g) were freeze-dried, ground and extracted successively with hexane (HEX), dichloromethane (DCM), DCM: $\mathrm{MeOH}$ (1:1) and $\mathrm{MeOH}$ (HmbG Chemicals). For each solvent, the suspension of ground leaves in 250-300 ml of solvent was shaken for $1 \mathrm{~h}$ on the orbital shaker. After filtering, the samples were extracted two more times for each solvent. Solvents were removed with a rotary evaporator to obtain the dried extracts, which were stored at $-20^{\circ} \mathrm{C}$ for further analysis.

\section{Antiproliferative activity}

Antiproliferative (APF) activity of extracts $(25 \mu \mathrm{g} / \mathrm{ml})$ was initially screened for growth inhibitory activity against three human cancer cell lines (MCF-7, MDAMB-231 and HeLa) using the sulphorhodamine B (SRB) assay [23]. Growth inhibitory activity with less than $50 \%$ cell growth was considered positive while that with more than $50 \%$ cell growth was considered negative. Extracts with positive growth inhibition were further tested against six human cancer lines (MCF-7, MDAMB-231, HeLa, HT-29, SKOV-3 and HepG2) using six different extract concentrations. Human cancer cell lines were obtained from the American Type Culture Collection (ATCC, Manassas, VA, USA). The cells were seeded $24 \mathrm{~h}$ prior to treatment in 96-well plates at densities of 10,000-20,000 cells/well. Each cell line was designated one plate. Initial cell population of each cell lines prior to addition of extracts was determined by fixing with trichloroacetic acid (TCA) (Sigma). Extracts were dissolved in dimethyl sulphoxide (DMSO) (Sigma) and serially diluted from $8-25 \mu \mathrm{g} / \mathrm{ml}$. Control cultures were treated with the same volume of DMSO. The concentration of DMSO was kept within 1\% to avoid any interference with cell viability. After the addition of extracts, the plates were incubated for $48 \mathrm{~h}$. After incubation, the cells were fixed with $50 \mu \mathrm{l}$ of cold $50 \%$ TCA and incubated for $1 \mathrm{~h}$ at $4^{\circ} \mathrm{C}$. The plates were then washed with tap water and air dried. Cells were stained with $100 \mu \mathrm{l}$ of $0.4 \%$ SRB solution (Sigma) diluted with $1 \%$ acetic acid followed by incubation for $10 \mathrm{~min}$ at room temperature. Unbound dye was removed by washing with $1 \%$ acetic acid. Bound stain was then solubilised with $200 \mu \mathrm{l}$ of $10 \mathrm{mM}$ trizma base (Sigma). Absorbance of each well at $505 \mathrm{~nm}$ was obtained using a microplate reader. Dose-response curves were constructed to obtain $\mathrm{GI}_{50}$ or concentration of extract that causes growth inhibition (GI) of cells by $50 \%$ GI $_{50}$ was calculated using the formula $\left[\left(\mathrm{T}_{\mathrm{z}}-\mathrm{T}_{\mathrm{i}}\right) /\left(\mathrm{T}_{\mathrm{c}}-\mathrm{T}_{\mathrm{i}}\right)\right] \times$ $100=50$ where $T_{z}$ is the absorbance of cells treated with extracts or drugs at the end of incubation, $T_{i}$ is the absorbance of cells prior to treatment with extracts or drugs and $T_{c}$ is the absorbance of untreated cells at the end of incubation [24]. $\mathrm{IC}_{50}$ or inhibition concentration 
at which there is a $50 \%$ reduction in cells was obtained using the formula $\mathrm{T}_{\mathrm{z}} / \mathrm{T}_{\mathrm{c}} \times 100=50$. Activity is considered to be effective when $\mathrm{GI}_{50}$ value $\leq 20 \mu \mathrm{g} / \mathrm{ml}$ [25].

\section{Antiplasmodial activity}

Antiplasmodial (APM) activity of extracts was assessed in vitro in human blood using the lactate dehydrogenase assay with slight modifications [26]. Chloroquineresistant $\mathrm{K} 1$ and chloroquine-sensitive $3 \mathrm{D} 7$ strains of Plasmodium falciparum were tested. Standard drugs of artemisinin (Sigma) and mefloquine (Sigma) were used as positive controls. Extracts dissolved in DMSO $(10 \mathrm{mg} / \mathrm{ml})$ were diluted with deionised water to 320 $\mu \mathrm{g} / \mathrm{ml}$. The solution was serially diluted two-fold six times to give seven different concentrations. Aliquots of each concentration $(10 \mu \mathrm{l})$ were transferred into 96-well microtiter plates. Parasitised red blood cell suspensions (1\% parasitaemia, $190 \mu \mathrm{l}$ ) were added to each well. Parasitised and non-parasitised red blood cells were used as negative controls. The plates were incubated for $24 \mathrm{~h}$ at $37^{\circ} \mathrm{C}$ in a candle jar and were subsequently chilled at $-20^{\circ} \mathrm{C}$ to lyse the red blood cells. The plates were then allowed to cool to room temperature, and $20 \mu \mathrm{l}$ of blood suspension was dispensed into a new microtiter plate containing $100 \mu \mathrm{l}$ MALSTAT TM reagent (Flow Inc.), and $20 \mu \mathrm{l}$ of nitroblue tetrazolium (Sigma) and phenazine ethosulphate (Sigma) mixture. Absorbance was measured with a plate reader at $630 \mathrm{~nm}$. Percentage inhibition at each concentration was determined and the mean of $\mathrm{EC}_{50}$ values of parasite viability was calculated using probit analysis. $\mathrm{EC}_{50}$ or effective concentration is the extract concentration that kills $50 \%$ of malaria parasites. Activity is effective if $\mathrm{EC}_{50}$ value $\leq 10 \mu \mathrm{g} / \mathrm{ml}$ [27]. The selectivity index (SI) for APM activity was calculated based on the ratio of cytotoxicity $\left(\mathrm{IC}_{50}\right)$ on HepG2 and MCF-7 cells to APM activity $\left(\mathrm{EC}_{50}\right)$ on chloroquine-resistant K1 strain.

\section{Analysis of TAC, TPC and RSA Total alkaloid content}

Total alkaloid content (TAC) of extracts was determined using the Dragendorff precipitation assay [28]. For each species, extracts $(15 \mathrm{mg}$ ) were dissolved in $1 \mathrm{ml}$ of distilled water that was acidified to $\mathrm{pH} 2.0-2.5$ with $0.01 \mathrm{M}$ $\mathrm{HCl}$. Analysis was conducted in triplicate. Alkaloids were then precipitated with $0.4 \mathrm{ml}$ of Dragendorff reagent. After washing with $0.5 \mathrm{ml}$ of distilled water to remove traces of the reagent, the precipitate was later treated with $0.4 \mathrm{ml}$ of $1 \%$ sodium sulphide, resulting in a brownish-black precipitate. Precipitates formed at each stage were recovered by centrifugation at 14,000 rpm for $1 \mathrm{~min}$. The resulting precipitate was dissolved in $0.2 \mathrm{ml}$ of concentrated nitric acid and diluted to $1 \mathrm{ml}$ with distilled water. Addition of $2.5 \mathrm{ml}$ of $3 \%$ thiourea to $0.5 \mathrm{ml}$ aliquots of this solution resulted in a yellow colored complex. Absorbance was measured at $435 \mathrm{~nm}$ and TAC was expressed as boldine equivalent in milligram per gram of extract. The calibration equation for boldine (Sigma) was y $=1.068 \mathrm{x}\left(R^{2}=0.9959\right)$ where $\mathrm{y}$ is absorbance and $\times$ is $\mathrm{mg} / \mathrm{ml}$ of boldine. Dragendorff reagent was prepared by dissolving $0.8 \mathrm{~g}$ of bismuth nitrate (Sigma) in $40 \mathrm{ml}$ of distilled water and $10 \mathrm{ml}$ of glacial acetic acid. The resulting solution was mixed with $20 \mathrm{ml}$ of $40 \%$ potassium iodide.

\section{Total phenolic content}

Total phenolic content (TPC) of extracts was determined using the Folin-Ciocalteu (FC) assay [29-31]. Extracts $(300 \mu \mathrm{l}$ in triplicate) were introduced into test tubes followed by $1.5 \mathrm{ml}$ of FC reagent (Fluka) at 10 times dilution and $1.2 \mathrm{ml}$ of sodium carbonate (Fluka) at $7.5 \% \mathrm{w} / \mathrm{v}$. The tubes were allowed to stand for $30 \mathrm{~min}$ in the dark before absorbance was measured at $765 \mathrm{~nm}$. TPC was expressed as gallic acid (GA) equivalent in milligram per gram of extract. The calibration equation for GA (Fluka) was $\mathrm{y}=0.0111 \mathrm{x}-0.0148\left(R^{2}=0.9998\right)$ where $y$ is absorbance and $x$ is $\mathrm{mg} / \mathrm{ml}$ of $\mathrm{GA}$.

\section{Radical-scavenging activity}

Radical-scavenging activity (RSA) of extracts was determined using the 1,1-diphenyl-2-picrylhydrazyl (DPPH) assay [29-31]. Different dilutions of extracts (1 $\mathrm{ml}$ in triplicate) were added to $2 \mathrm{ml}$ of DPPH (Sigma). The concentration of DPPH used was $5.9 \mathrm{mg}$ in $100 \mathrm{ml}$ of methanol. Absorbance was measured at $517 \mathrm{~nm}$ after 30 min. RSA was calculated as $\mathrm{IC}_{50}$, the concentration of extract to scavenge $50 \%$ of the DPPH radical. RSA was then expressed as ascorbic acid equivalent antioxidant capacity (AEAC) using the equation: AEAC (mg ascorbic acid $/ \mathrm{g})=\mathrm{IC}_{50 \text { (ascorbate) }} / \mathrm{IC}_{50 \text { (sample) }} \times 10^{5} . \mathrm{IC}_{50}$ of ascorbic acid used for calculation of AEAC was 0.00387 $\mathrm{mg} / \mathrm{ml}$.

\section{Phytochemical screening}

Qualitative phytochemical screening for saponins, tannins, cardenolides and terpenoids from leaf extracts of $V$. glabra was carried out using standard phytochemical procedures $[32,33]$. The frothing test was used for saponins, the ferric chloride test for tannins, the Kedde test for cardenolides and the vanillin- $\mathrm{H}_{2} \mathrm{SO}_{4}$ test for terpenoids.

\section{Results and Discussion \\ APF activity}

Initial screening of leaf extracts of five Apocynaceae species against three human cancer cell lines (MCF-7, MDA-MB-231 and HeLa) showed that DCM, DCM: $\mathrm{MeOH}$ and $\mathrm{MeOH}$ extracts of $A$. angustiloba, C. gigantea and $V$. glabra had growth inhibitory activity (data not shown). DCM and DCM:MeOH extracts of 
V. glabra, and DCM extract of C. gigantea inhibited all three cancer cell lines. HEX and $\mathrm{MeOH}$ extracts of all three species did not show inhibition, with the exception of $\mathrm{MeOH}$ extract of $V$. glabra. Extracts of $D$. costulata and $K$. fruticosa did not show any APF activity.

Extracts of the three species were further tested against six human cancer cell lines (MCF-7, MDA-MB-231, HeLa, HT-29, SKOV-3 and HepG2). Results showed that DCM extract of $A$. angustiloba inhibited only MDA-MB231, HeLa and SKOV-3 cell lines with $\mathrm{GI}_{50}$ values of 20, 20 and $16 \mu \mathrm{g} / \mathrm{ml}$, respectively (Table 1 ). DCM and DCM: $\mathrm{MeOH}$ extracts of $C$. gigantea inhibited all cancer cell lines except for DCM:MEOH extract against MDA-MB231. APF activity of DCM extract of $C$. gigantea was the strongest with $\mathrm{GI}_{50}$ values ranging from 1.3 to $3.3 \mu \mathrm{g} / \mathrm{ml}$. Against MCF-7 and MDA-MB-231, $\mathrm{GI}_{50}$ of DCM extract of C. gigantea (1.9 and $1.3 \mu \mathrm{g} / \mathrm{ml})$ was stronger than that of xanthorrhizol (11 and $8.7 \mu \mathrm{g} / \mathrm{ml})$, curcumin (4.1 and $8.7 \mu \mathrm{g} / \mathrm{ml})$ and tamoxifen $(8.3$ and $4.6 \mu \mathrm{g} / \mathrm{ml})$, respectively. DCM and DCM:MeOH extracts of $V$. glabra inhibited all cell lines with $\mathrm{GI}_{50}$ values ranging from 7.5$12 \mu \mathrm{g} / \mathrm{ml}$ and $5.8-13 \mu \mathrm{g} / \mathrm{ml}$, respectively. In addition, $\mathrm{MeOH}$ extract of $V$. glabra also inhibited the growth of MCF-7 and HepG2. Against MCF-7, GI 50 of DCM and DCM:MeOH extracts of $V$. glabra $(7.7$ and $7.0 \mu \mathrm{g} / \mathrm{ml})$ was stronger than xanthorrhizol $(11 \mu \mathrm{g} / \mathrm{ml})$ and comparable to tamoxifen $(8.3 \mu \mathrm{g} / \mathrm{ml})$, respectively.

To the best of our knowledge, this study represents the first report of cytotoxic activity from DCM leaf extract of A. angustiloba and DCM and DCM:MeOH extracts of $V$. glabra. Earlier studies have reported cytotoxic activity from the root bark of Alstonia macrophylla Wall. ex G. Don [12] and the stem bark of Alstonia scholaris R. Br. [13]. A recent study on Vallaris solanacea (Roth) Kuntz has reported potent cell growth inhibitory activity of cardenolide glycosides isolated from the plant [34]. The finding of strong APF activity from DCM and DCM:MeOH extracts of C. gigantea from this study is supported by an earlier report that DCM leaf extracts of $C$. gigantea had strong inhibitory activity against KB, BC and NCI-H187 cancer cell lines [35]. Ethanol root extracts of $C$. gigantea were also reported to be cytotoxic to K562 and SGC-7901 human cell lines [36].

\section{APM activity}

Against chloroquine-resistant K1 strain of P. falciparum, leaves of $V$. glabra were most effective as all four extracts had APM activity with $\mathrm{EC}_{50}$ less than $10 \mu \mathrm{g} / \mathrm{ml}$ (Table 2). DCM extract was the strongest with $\mathrm{EC}_{50}$ of $0.85 \mu \mathrm{g} / \mathrm{ml}$. Three extracts of $A$. angustiloba, and two extracts of C. gigantea, D. costulata and $K$. fruticosa showed APM activity. It should be noted that DCM: $\mathrm{MeOH}$ extracts of all five species displayed APM activity with $A$. angustiloba having the strongest activity $\left(\mathrm{EC}_{50}\right.$ of $0.46 \mu \mathrm{g} / \mathrm{ml})$.

Against chloroquine-sensitive 3D7 strain of $P$. falciparum, extracts of $A$. angustiloba and V. glabra showed

Table 1 Antiproliferative activity of leaf extracts of three Apocynaceae species against six human cancer cell lines ${ }^{\mathrm{a}}$

\begin{tabular}{|c|c|c|c|c|c|c|c|}
\hline \multirow[t]{2}{*}{ Species } & \multirow[t]{2}{*}{${ }^{\mathrm{C}}$ Leaf extract } & \multicolumn{6}{|c|}{${ }^{\mathrm{b}} \mathrm{GI}_{50}(\mu \mathrm{g} / \mathrm{ml})$} \\
\hline & & MCF-7 & MDA-MB-231 & HeLa & HT-29 & SKOV-3 & HepG2 \\
\hline \multirow[t]{4}{*}{ Alstonia angustiloba } & HEX & - & - & - & - & - & - \\
\hline & DCM & - & $20 \pm 1.7$ & $20 \pm 1.1$ & - & $16 \pm 1.4$ & - \\
\hline & DCM:MeOH & - & - & - & - & - & - \\
\hline & $\mathrm{MeOH}$ & - & - & - & - & - & - \\
\hline \multirow[t]{4}{*}{ Calotropis gigantea } & HEX & - & - & - & - & - & - \\
\hline & DCM & $1.9 \pm 0.2$ & $1.3 \pm 0.3$ & $2.5 \pm 0.5$ & $3.3 \pm 0.2$ & $2.5 \pm 0.2$ & $1.8 \pm 1.7$ \\
\hline & DCM:MeOH & $13 \pm 0.3$ & - & $15 \pm 1.0$ & $24 \pm 0.7$ & $20 \pm 2.3$ & $16 \pm 3.5$ \\
\hline & $\mathrm{MeOH}$ & - & - & - & - & - & - \\
\hline \multirow[t]{4}{*}{ Vallaris glabra } & HEX & - & - & - & - & - & - \\
\hline & DCM & $7.7 \pm 1.3$ & $12 \pm 2.0$ & $9.8 \pm 1.5$ & $9.3 \pm 2.0$ & $7.5 \pm 4.5$ & $7.6 \pm 0.2$ \\
\hline & DCM:MeOH & $7.0 \pm 2.5$ & $13 \pm 6.3$ & $8.5 \pm 2.9$ & $12 \pm 1.2$ & $7.7 \pm 2.4$ & $5.8 \pm 1.2$ \\
\hline & $\mathrm{MeOH}$ & $16 \pm 2.1$ & - & - & - & - & $19 \pm 0.9$ \\
\hline \multicolumn{8}{|c|}{${ }^{\mathrm{d}}$ Standard drug } \\
\hline \multicolumn{2}{|c|}{ Xanthorrhizol } & $11 \pm 0.7$ & $8.7 \pm 0.8$ & & & & \\
\hline \multicolumn{2}{|c|}{ Curcumin } & $4.1 \pm 0.9$ & $8.7 \pm 0.8$ & & & & \\
\hline \multicolumn{2}{|c|}{ Tamoxifen } & $8.3 \pm 0.6$ & $4.6 \pm 0.5$ & & & & \\
\hline
\end{tabular}

\footnotetext{
${ }^{a}$ Initial screening showed that extracts of Dyera costulata and Kopsia fruticosa did not show any APF activity.

${ }^{\mathrm{b}} \mathrm{Gl}_{50}(\mu \mathrm{g} / \mathrm{ml})$ is growth inhibition (GI) of cancer cell lines by $50 \%$. Inhibition is not effective (-) with values $>20 \mu \mathrm{g} / \mathrm{ml}$. MCF-7 and MDA-MB-231, HeLa and SKOV-

3, HT-29, and HepG2 are human breast, cervical, colon and liver cancer cell lines, respectively.

' HEX, hexane; DCM, dichloromethane; $\mathrm{MeOH}$, methanol.

${ }^{\mathrm{d}}$ Data on standard drugs of xanthorrhizol, curcumin and tamoxifen against MCF-7 and MDA-MD-231 cell lines are from an earlier publication [24].
} 
Table 2 Antiplasmodial (APM) activity and selectivity index (SI) of leaf extracts of Apocynaceae species

\begin{tabular}{|c|c|c|c|c|c|c|c|}
\hline \multirow[t]{2}{*}{ Species } & \multirow[t]{2}{*}{${ }^{C}$ Leaf extract } & \multicolumn{2}{|c|}{${ }^{\mathrm{a}} \mathrm{EC}_{50}(\mu \mathrm{g} / \mathrm{ml})$ of APM activity } & \multicolumn{2}{|c|}{${ }^{b} \mathrm{IC}{ }_{50}(\mu \mathrm{g} / \mathrm{ml})$ of APF activity } & \multicolumn{2}{|c|}{${ }^{\mathrm{b}} \mathrm{SI}$ of APM activity } \\
\hline & & K1 & 3D7 & HepG2 & MCF-7 & HepG2 & MCF-7 \\
\hline \multirow[t]{4}{*}{ Alstonia angustiloba } & HEX & 7.81 & - & & & & \\
\hline & DCM & - & - & & & & \\
\hline & DCM:MeOH & 0.46 & - & $>25.0$ & $>25.0$ & NC & NC \\
\hline & $\mathrm{MeOH}$ & 6.46 & - & & & & \\
\hline \multirow[t]{4}{*}{ Calotropis gigantea } & HEX & 5.82 & - & & & & \\
\hline & DCM & - & - & & & & \\
\hline & DCM:MeOH & 0.97 & 3.29 & $>25.0$ & 16.8 & NC & 17.3 \\
\hline & $\mathrm{MeOH}$ & - & - & & & & \\
\hline \multirow[t]{4}{*}{ Dyera costulata } & HEX & - & - & & & & \\
\hline & DCM & - & 8.31 & & & & \\
\hline & DCM:MeOH & 7.52 & 2.13 & & & & \\
\hline & $\mathrm{MeOH}$ & 7.74 & 3.56 & & & & \\
\hline \multirow[t]{4}{*}{ Kopsia fruticosa } & HEX & - & - & & & & \\
\hline & DCM & - & 7.14 & & & & \\
\hline & DCM:MeOH & 4.35 & - & & & & \\
\hline & $\mathrm{MeOH}$ & 1.01 & - & & & & \\
\hline \multirow[t]{4}{*}{ Vallaris glabra } & HEX & 1.00 & - & $>25.0$ & $>25.0$ & NC & NC \\
\hline & DCM & 0.85 & - & $>25.0$ & 12.0 & NC & 14.1 \\
\hline & DCM:MeOH & 8.45 & - & & & & \\
\hline & $\mathrm{MeOH}$ & 8.42 & - & & & & \\
\hline \multicolumn{8}{|c|}{${ }^{\mathrm{d}}$ Standard drug } \\
\hline \multicolumn{2}{|c|}{ Artemisinin } & 0.001 & 0.001 & & & & \\
\hline \multicolumn{2}{|c|}{ Mefloquine } & 0.008 & 0.018 & & & & \\
\hline
\end{tabular}

${ }^{\mathrm{a}} \mathrm{EC}_{50}$ or effective concentration $(\mu \mathrm{g} / \mathrm{ml})$ is the extract concentration that kills $50 \%$ of malaria parasites. Activity is not effective $(-)$ if $\mathrm{EC} \mathrm{C}_{50}$ value $>10 \mu \mathrm{g} / \mathrm{ml}$. $\mathrm{K} 1$ and 3D7 are chloroquine-resistant and chloroquine-sensitive strains of Plasmodium falciparum, respectively.

${ }^{\mathrm{b}} \mathrm{IC}_{50}$ of antiproliferative (APF) activity and SI of APM activity against HepG2 and MCF-7 cells were calculated only for the most potent extracts against K1 strain with $\mathrm{EC}_{50} \leq 1.00 \mu \mathrm{g} / \mathrm{ml}$. NC, non-cytotoxic with SI values $>25.0$.

c $\mathrm{HEX}$, hexane; $\mathrm{MeOH}$, methanol; DCM, dichloromethane.

d Standard drugs of artemisinin and mefloquine are used as positive controls.

no activity. Extracts of D. costulata were the exception in that DCM, DCM:MeOH and $\mathrm{MeOH}$ extracts showed positive APM activity with $\mathrm{EC}_{50}$ of $8.31,2.13$ and 3.56 $\mu \mathrm{g} / \mathrm{ml}$, respectively. Generally, extracts were less effective against 3D7 strain.

This finding complements an earlier report that alkaloids from the extracts of Alstonia species were effective against chloroquine-resistant $\mathrm{K} 1$ strain but not against chloroquine-sensitive T9-96 strain [22]. Previous studies on the APM activity of Apocynaceae were focused on Alstonia species [21,22]. This study is the first to report the APM activity of leaf extracts of $D$. costulata, $C$. gigantea, K. fruticosa and V. glabra. A notable finding is the APM activity of $V$. glabra against K1 strain in all solvent fractions.

\section{Selectivity index}

The selectivity index (SI) for APM activity indicates the safety of an extract to be used for antimalarial therapy [37]. The index was calculated based on the ratio of cytotoxicity $\left(\mathrm{IC}_{50}\right)$ on HepG2 and MCF-7 cells to APM activity $\left(\mathrm{EC}_{50}\right)$. The SI was calculated for the most potent extracts against $\mathrm{K} 1$ strain of $P$. falciparum with $\mathrm{EC}_{50} \leq 1.00 \mu \mathrm{g} / \mathrm{ml}$. They were DCM:MeOH extracts of $A$. angustiloba $(0.46 \mu \mathrm{g} / \mathrm{ml})$ and $C$. gigantea $(0.97 \mu \mathrm{g} / \mathrm{ml})$, and HEX and DCM extracts of $V$. glabra $(1.00$ and $0.85 \mu \mathrm{g} / \mathrm{ml}$ ), respectively (Table 2). Against HepG2 cells, $\mathrm{IC}_{50}$ values were all $>25.0 \mu \mathrm{g} / \mathrm{ml}$, and against MCF-7 cells, $\mathrm{IC}_{50}$ values were $>25.0,16.8,>25.0$ and $12.0 \mu \mathrm{g} / \mathrm{ml}$, respectively.

Against HepG2 cells, HEX and DCM extracts of $V$. glabra, and DCM:MeOH extracts of A. angustiloba and C. gigantea were non-cytotoxic with SI values $>25.0$ (Table 2). Against MCF-7 cells, the DCM extract of $V$. glabra and the DCM:MeOH extract of C. gigantea had SI values of 14.1 and 17.3 , respectively. The HEX extract of $V$. glabra and the DCM:MeOH extract of $A$. angustiloba were non-cytotoxic with SI values $>25.0$.

Recently, a study on the antimalarial and cytotoxic activity of plants in the Democratic Republic of Congo considered SI values of extracts $>10$ as high [38]. With SI values relatively higher than 10 , the extracts of $A$. angustiloba, 
C. gigantea and V. glabra are potentially safe for use to treat malaria.

\section{Analysis of TAC, TPC and RSA}

Of the five species analysed, $\mathrm{MeOH}$ crude and DCM extracts of $K$. fruticosa had the highest TAC (100 and $129 \mathrm{mg} \mathrm{BE} / \mathrm{g}$ of extract), respectively (Table 3). Other species with high TAC were $D$. costulata and $A$. angustiloba with $\mathrm{MeOH}$ crude and DCM:MeOH extracts having values in the range $58-68$ and $23-58 \mathrm{mg} \mathrm{BE} / \mathrm{g}$ of extract, respectively. Based on TAC, the ranking of species was: K. fruticosa $>D$. costulata $>A$. angustiloba $>C$. gigantea $\approx V$. glabra. Extracts of $D$. costulata had the highest TPC and strongest RSA. MeOH crude, DCM: $\mathrm{MeOH}$ and $\mathrm{MeOH}$ extracts yielded TPC values of 319, 354 and $279 \mathrm{mg}$ GAE/g of extract, and RSA values of 377,349 and $278 \mathrm{mg} \mathrm{AA} / \mathrm{g}$ of extract, respectively. Based on TPC and RSA, the ranking of species was: $D$. costulata $>V$. glabra $>K$. fruticosa $>A$. angustiloba $>C$. gigantea. There is a strong correlation between TPC and RSA of extracts $\left(R^{2}=0.955\right)$ but not with TAC $\left(R^{2}=0.112\right)$. Correlation of results of phytochemical analysis with APF and APM activities remains unclear. Extracts of C. gigantea and V. glabra showed strong APF activity. The former had low TAC and TPC, while the latter had low TAC but high TPC. Extracts of $V$. glabra and D. costulata were effective against $\mathrm{K} 1$ and 3D7 strains of P. falciparum, respectively. The former had low TAC but high TPC, while the latter had high TAC and TPC.

\section{Phytochemical screening}

Phytochemical screening showed the presence of terpenoids in all leaf extracts of $V$. glabra except $\mathrm{MeOH}$ extract while saponins and tannins were present in DCM and DCM:MeOH extracts, and in DCM:MeOH and $\mathrm{MeOH}$ extracts, respectively (Table 4). Cardenolides were not detected.

Terpenoids are used for the treatment of human diseases such as cancer and malaria, and infectious diseases caused by virus and bacterial [39]. Taxol and artimesinin are renowned terpenoid-based anticancer and antimalarial drugs, respectively. Terpenoids inhibit the growth or induce apoptosis of breast cancer cells such as MCF-7, MDA-MB-231 and T47D [40]. They are among the most important natural antimalarial drugs, which also include quinones and alkaloids [41].

Tannins are water-soluble polyphenols that are present in many plant foods [42]. Literature on the effects of tannins on human health is vast and sometimes conflicting. Incidences of esophageal cancer have been attributed to consumption of tannin-rich foods such as herbal teas, suggesting that tannins might be carcinogenic. However, reports have indicated a negative association between consumption of tea and the incidence of cancer. Teas with high tannin content have been suggested to be anticarcinogenic

Table 3 Phytochemical analysis of total alkaloid content, total phenolic content and radical-scavenging activity of leaf extracts of Apocynaceae species

\begin{tabular}{|c|c|c|c|c|c|}
\hline \multirow[t]{2}{*}{ Species } & \multirow[t]{2}{*}{ MeOH crude extract } & \multicolumn{4}{|c|}{${ }^{\mathrm{a} S}$ Sequential extract } \\
\hline & & HEX & DCM & DCM:MeOH & $\mathrm{MeOH}$ \\
\hline \multicolumn{6}{|c|}{${ }^{\mathrm{b}}$ Total alkaloid content (mg BE/g) } \\
\hline Kopsia fruticosa & $100 \pm 4.2$ & $63 \pm 1.1$ & $129 \pm 4.0$ & $99 \pm 2.5$ & $46 \pm 1.6$ \\
\hline Dyera costulata & $58 \pm 2.5$ & $2.4 \pm 0.6$ & $11 \pm 1.8$ & $68 \pm 2.7$ & $41 \pm 2.4$ \\
\hline Alstonia angustiloba & $23 \pm 0.3$ & $13 \pm 2.3$ & $27 \pm 3.1$ & $58 \pm 1.2$ & $27 \pm 1.0$ \\
\hline Calotropis gigantea & $2.7 \pm 0.3$ & $3.7 \pm 1.0$ & $8.6 \pm 1.2$ & $9.6 \pm 1.9$ & $9.2 \pm 2.7$ \\
\hline Vallaris glabra & $2.7 \pm 0.4$ & $4.4 \pm 0.8$ & $8.9 \pm 0.6$ & $9.2 \pm 0.2$ & $8.7 \pm 2.2$ \\
\hline \multicolumn{6}{|c|}{${ }^{\mathrm{b}}$ Total phenolic content (mg GAE/g) } \\
\hline Dyera costulata & $319 \pm 5.5$ & $21 \pm 0.2$ & $23 \pm 0.1$ & $354 \pm 6.0$ & $279 \pm 3.0$ \\
\hline Vallaris glabra & $99 \pm 3.8$ & $15 \pm 0.9$ & $24 \pm 0.5$ & $134 \pm 1.0$ & $164 \pm 13$ \\
\hline Kopsia fruticosa & $83 \pm 1.1$ & $39 \pm 0.5$ & $20 \pm 0.5$ & $129 \pm 1.0$ & $84 \pm 1.0$ \\
\hline Alstonia angustiloba & $68 \pm 2.0$ & $17 \pm 0.6$ & $24 \pm 0.6$ & $96 \pm 1.1$ & $94 \pm 1.1$ \\
\hline Calotropis gigantea & $28 \pm 0.8$ & $14 \pm 0.6$ & $44 \pm 1.7$ & $42 \pm 0.8$ & $33 \pm 0.5$ \\
\hline \multicolumn{6}{|c|}{${ }^{\mathrm{b}}$ Radical-scavenging activity (mg AA/g) } \\
\hline Dyera costulata & $377 \pm 25$ & $15 \pm 0.3$ & $9.3 \pm 0.5$ & $349 \pm 21$ & $278 \pm 5.4$ \\
\hline Vallaris glabra & $84 \pm 0.5$ & $6.0 \pm 0.3$ & $8.4 \pm 0.4$ & $77 \pm 2.2$ & $119 \pm 6.8$ \\
\hline Kopsia fruticosa & $63 \pm 3.2$ & $12 \pm 1.4$ & $7.5 \pm 0.3$ & $70 \pm 2.0$ & $48 \pm 1.5$ \\
\hline Alstonia angustiloba & $29 \pm 0.9$ & $10 \pm 0.2$ & $5.7 \pm 0.7$ & $50 \pm 1.2$ & $46 \pm 2.2$ \\
\hline Calotropis gigantea & $7.6 \pm 0.4$ & $5.6 \pm 0.3$ & $6.1 \pm 0.4$ & $8.0 \pm 0.6$ & $14 \pm 1.3$ \\
\hline
\end{tabular}

${ }^{a} \mathrm{HEX}$, hexane; DCM, dichloromethane; $\mathrm{MeOH}$, methanol.

${ }^{b} \mathrm{BE}$, boldine equivalent; $\mathrm{GAE}$, gallic acid equivalent; $\mathrm{AA}$, ascorbic acid. Values are in milligram per gram of extract. 
Table 4 Phytochemical screening of leaf extracts of Vallaris glabra

\begin{tabular}{lcccc}
\hline${ }^{\text {a Leaf extract }}$ & \multicolumn{4}{c}{${ }^{\mathbf{b}}$ Qualitative test } \\
\cline { 2 - 5 } & ${ }^{\text {c }}$ Saponin & ${ }^{\mathrm{C}}$ Tannin & ${ }^{\mathrm{C}}$ Cardenolide & ${ }^{\mathrm{c}}$ Terpenoid \\
\hline $\mathrm{HEX}$ & - & - & - & +++ \\
$\mathrm{DCM}$ & + & - & - & ++ \\
$\mathrm{DCM}: \mathrm{MeOH}$ & ++ & ++ & - & ++ \\
$\mathrm{MeOH}$ & - & ++ & - & - \\
\hline
\end{tabular}

${ }^{a}$ HEX, hexane; DCM, dichloromethane; $\mathrm{MeOH}$, methanol.

b Strong (+++), moderate (++) and weak (+) presence, and absent (-). Classification was based on observation of colour intensity and amount of precipitate.

c Saponins, tannins, cardenolides and terpenoids were screened using the frothing, ferric chloride, Kedde and vanillin- $\mathrm{H}_{2} \mathrm{SO}_{4}$ tests.

and antimutagenic which may be related to their antioxidative property in protecting cellular oxidative damage against lipid peroxidaton and superoxide radicals. The antimicrobial activities of tannins are well documented.

Saponins are naturally occurring glycosides with a distinctive foaming characteristic and bitter taste $[43,44]$. They have a wide range of properties, which include both beneficial and detrimental effects on human health. Saponins affect the immune system in ways that help to protect the human body against cancers, and also lower cholesterol levels. They decrease blood lipids, lower cancer risks and lower blood glucose response.

\section{Conclusions}

The DCM extract of C. gigantea, and DCM and DCM: $\mathrm{MeOH}$ extracts of $V$. glabra inhibited the growth of all six human cancer cell lines. Against MCF-7 and MDAMB-231 human cell lines, DCM leaf extract of C. gigantea had stronger APF activity than standard drugs of xanthorrhizol, curcumin and tamoxifen. With wide spectrum APF activity, leaves of these two species are therefore promising candidates as alternative resources for anticancer drugs. Against K1 strain of P. falciparum, all four extracts of $V$. glabra displayed effective APM activity. Selectivity index values suggested that extracts of $V$. glabra are potentially safe for use to treat malaria. The wide spectrum APF and APM activities of $V$. glabra are reported for the first time. This warrants further investigation into its bioactive compounds.

\section{Acknowledgements}

The authors are thankful to Monash University Sunway Campus (MUSC) and the Institute of Medical Research (IMR) for funding and supporting the project. The assistance of HT Chan in identifying and locating the plant species is gratefully acknowledged.

\section{Author details}

${ }^{1}$ School of Science, Monash University Sunway Campus, Bandar Sunway, 46150 Petaling Jaya, Selangor, Malaysia. ${ }^{2}$ Herbal Medicine Research Centre, Institute for Medical Research, 50588 Kuala Lumpur, Malaysia.

\section{Authors' contributions}

The study was conducted by SKW as part of her PhD program in Monash University Sunway Campus in Malaysia which is supervised by YYL. Part of the experiments was done in collaboration with Noor Rain and Fariza Juliana from the Institute of Medical Research. SKW analysed the data and drafted the manuscript which was edited and revised by $Y Y L$, with comments from counterparts. All authors read and approved the final manuscript.

\section{Competing interests}

The authors declare that they have no competing interests.

Received: 11 October 2010 Accepted: 14 January 2011

Published: 14 January 2011

\section{References}

1. Ng FSP: Tropical Horticulture and Gardening Clearwater Publications, Kuala Lumpur, Malaysia; 2006.

2. Wiart C: Medicinal Plants of Asia and the Pacific CRC Press/Taylor \& Francis, Boca Raton; 2006.

3. Rajakaruna N, Harris CS, Towers GHN: Antimicrobial activity of plants collected from serpentine outcrops in Sri Lanka. Pharm Biol 2002, 40:235-244.

4. Nalwaya N, Pokharna G, Deb L, Jain NK: Wound healing activity of latex of Calotropis gigantea. Inter J Pharm Pharm Sci 2009, 1:176-181.

5. Johnson T: CRC Ethnobotany Desk Reference Cleveland, Ohio: CRC Press LLC; 1999.

6. Subhadhirasakul S, Jankeaw B, Malinee A: Chemical constituents and antioxidative activity of the extract from Dyera costulata leaves. Songklanakarin J Sci Technol 2003, 25:351-357.

7. Mulyoutami E, Rismawan R, Joshi L: Local knowledge and management of simpukng (forest gardens) among the Dayak people in East Kalimantan, Indonesia. Forest Ecol Manage 2009, 257:2054-2061.

8. Lin KW: Ethnobotanical study of medicinal plants used by the Jah Hut people in Malaysia. Indian J Med Sci 2005, 59:156-161.

9. Wongpornchai $\mathrm{S}$, Sriseadka T, Choonvisase S: Identification and quantitation of the rice aroma compound, 2-acetyl-1-pyrroline, in bread flowers (Vallaris glabra Ktze). J Agric Food Chem 2003, 51:457-462.

10. Patel B, Das S, Prakash R, Yasir M: Natural bioactive compound with anticancer potential. Inter J Adv Pharm Sci 2010, 1:32-41.

11. Schmidt DFN, Yunes RA, Schaab EH, Malheiros A, Filho VC, Franchi GC Jr, Nowill AE, Cardoso AA, Yunes JA: Evaluation of the anti-proliferative effect the extracts of Allamanda blanchetti and A. schottii on the growth of leukemic and endothelial cells. J Pharm Pharm Sci 2006, 9:200-208.

12. Keawpradub N, Eno-Amooquaye E, Burke PJ, Houghton PJ: Cytotoxic activity of indole alkaloids from Alstonia macrophylla. Planta Med 1999, 65:311-315.

13. Jagetia GC, Baliga MS: Evaluation of anticancer activity of the alkaloid fraction of Alstonia scholaris (Sapthaparna) in vitro and in vivo. Phytother Res 2006, 20:103-109.

14. Chang LC, Gills JJ, Bhat KPL, Luyengi L, Farnsworth NR, Pezzuto JM, Kinghorn AD: Activity-guided isolation of constituents of Cerbera manghas with antiproliferative and antiestrogenic activities. Bioorg Med Chem Lett 2000, 10:2431-2434.

15. Nurhanan MY, Asiah O, Mohd Ilham MA, Siti Syarifah MM, Norhayati I, Lili Sahira H: Anti-proliferative activities of 32 Malaysian plant species in breast cancer cell lines. J Trop Forest Sci 2008, 20:77-81.

16. Siddiqui BS, Begum S, Siddiqui S, Lichter W: Two cytotoxic pentacyclic triterpenoids from Nerium oleander. Phytochemistry 1995, 39:171-174.

17. Pathak S, Multani AS, Narayan S, Kumar V, Newman RA: Anvirzel ${ }^{\mathrm{TM}}$, an extract of Nerium oleander, induces cell death in human but not murine cancer cells. Anti-Cancer Drugs 2000, 11:455-463.

18. Kardono LSS, Tsauri S, Padmawinata K, Pezzuto JM, Kinghorn AD: Cytotoxic constituents of the bark of Plumeria rubra collected in Indonesia. J Nat Prod 1990, 53:1447-1455.

19. Lee CC, Houghton P: Cytotoxicity of plants from Malaysia and Thailand used traditionally to treat cancer. J Ethnopharmacol 2005, 100:237-243.

20. Schwikkard S, van Heerden FR: Antimalarial activity of plant metabolites. Nat Prod Rep 2002, 19:675-692. 
21. Wright CW, Allen D, Phillipson JD, Kirby GC, Warhurst DC, Massiot G, Le Men-Olivier L: Alstonia species: are they effective in malaria treatment? J Ethnopharmacol 1993, 40:41-45.

22. Keawpradub N, Kirby GC, Steele JCP, Houghton PJ: Antiplasmodial activity of extracts and alkaloids of Thai Alstonia species from Thailand. Planta Med 1999, 65:690-694.

23. Vichai V, Kirtikara K: Sulforhodamine B colorimetric assay for cytotoxicity screening. Nat Protoc 2006, 1:1112-1116.

24. Cheah YH, Nordin FJ, Tee $\Pi$, Azimahtol HLP, Abdullah NR, Ibrahim Z: Antiproliferative property and apoptotic effect of xanthorrhizol on MDA231 breast cancer cells. Anticancer Res 2008, 28:3677-3690.

25. Gaidhani SN, Lavekar GS, Juvekar AS, Sen S, Singh A, Kumari S: In-vitro anticancer activity of standard extracts used in ayurveda. Pharmacog Mag 2009, 5:425-429.

26. Chan KL, Choo CY, Abdullah NR, Ibrahim Z: Antiplasmodial studies of Eurycoma longifolia using the lactate dehydrogenase assay of Plasmodium falciparum. J Ethnopharmacol 2004, 92:223-227.

27. Tran QL, Tezuka Y, Ueda JY, Nguyen NT, Maruyama Y, Begum K, Kim HS, Wataya Y, Tran QK, Kadota S: In vitro antiplasmodial activity of antimalarial medicinal plants used in Vietnamese traditional medicine. J Ethnopharmacol 2003, 86:249-252.

28. Ribeiro B, Lopes R, Andrade PB, Seabra RM, Goncalves RF, Baptista P, Quelhas I, Valentao P: Comparative study of phytochemicals and antioxidant potential of wild edible mushroom caps and stipes. Food Chem 2008, 110:47-56.

29. Wong SK, Lim YY, Chan EWC: Antioxidant properties of Hibiscus: Species variation, altitudinal change, coastal influence and floral colour change. J Trop Forest Sci 2009, 21:307-315.

30. Rao ASVC, Reddy SG, Babu PP, Reddy AR: The antioxidant and antiproliferative activities of methanolic extracts from Njavara rice bran. BMC Complement Altern Med 2010, 10:4.

31. Lai HY, Lim YY, Kim KH: Blechnum orientale Linn - a fern with potential as antioxidant, anticancer and antibacterial agent. BMC Complement Altern Med 2010, 10:15

32. Harborne JB: Phytochemical Method: A Guide to Modern Techniques of Plants Analysis. Third edition. New York: Chapman and Hall; 1998.

33. Houghton PJ, Raman A: Laboratory Handbook for the Fractionation of Natural Extracts New York: Chapman and Hall; 1998.

34. Ahmed F, Sadhu SK, Ohtsuki T, Khatun A, Ishibashi M: Glycosides from Vallaris solanacea with TRAIL resistance overcoming activity. Heterocycles 2010, 80:477-488.

35. Lhinhatrakool T, Sutthivaiyakit S: 19-Nor- and 18,20-epoxy-cardenolides from the leaves of Calotropis gigantea. J Nat Prod 2006, 69:1249-1251.

36. Wang ZH, Wang MY, Mei WL, Han Z, Dai HF: A new cytotoxic pregnanone from Calotropis gigantea. Molecules 2008, 13:3033-3039.

37. Esmaeili S, Naghibi F, Mosaddegh M, Sahranavard S, Ghafari S, Abdullah NR: Screening of antiplasmodial properties among some traditionally used Iranian plants. J Ethnopharmacol 2009, 121:400-404.

38. Lusakibanza M, Mesia G, Tona G, Karemere S, Lukuka A, Tits M, Angenot L, Frédérich M: In vitro and in vivo antimalarial and cytotoxic activity of five plants used in congolese traditional medicine. J Ethnopharmacol 2010, 129:398-402.

39. Wang G, Tang W, Bidigare RR: Terpenoids as therapeutic drugs and pharmaceutical agents. In Natural Products Drug Discovery and Therapeutic Medicine. Edited by: Zhang L, Demain AL. Humana Press; 2005:197-227.

40. Rabi T, Bishayee A: Terpenoids and breast cancer chemoprevention. Breast Cancer Res Treat 2009, 115:223-239.

41. Caniato R, Puricelli L: Review: natural antimalarial agents (1995-2001). Crit Rev Plant Sci 2003, 22:79-105.

42. Chung KT, Wong TY, Wei Cl, Huang YW, Lin Y: Tannins and human health: a review. Crit Rev Food Sci Nutr 1998, 38:421-464.

43. Desai SD, Desai DG, Kaur H: Saponins and their biological activities. Pharma Times 2009, 41:13-16.

44. Shi J, Arunasalam K, Yeung D, Kakuda Y, Mittal G, Jiang Y: Saponins from edible legumes: chemistry, processing, and health benefits. J Med Food 2004, 7:67-78.

\section{Pre-publication history}

The pre-publication history for this paper can be accessed here: http://www.biomedcentral.com/1472-6882/11/3/prepub

doi:10.1186/1472-6882-11-3

Cite this article as: Wong et al:: Assessment of antiproliferative and antiplasmodial activities of five selected Apocynaceae species. BMC Complementary and Alternative Medicine 2011 11:3.

\section{Submit your next manuscript to BioMed Central and take full advantage of:}

- Convenient online submission

- Thorough peer review

- No space constraints or color figure charges

- Immediate publication on acceptance

- Inclusion in PubMed, CAS, Scopus and Google Scholar

- Research which is freely available for redistribution

Submit your manuscript at www.biomedcentral.com/submit
Biomed Central 